\title{
The Potential of Walnut Seeds (Canarium indicum L.) in Repairing the Genotoxicity Effect of Mercury on Mice Erythrocytes
}

Cakra Haryo Wibowo*
Essy Oktarina
Rafika Destiana Wardani
Khoirul Ngibad
Department of Medical Laboratory
Technology, Universitas Maarif Hasyim
Latif, Sidoarjo, East Java, Indonesia
*email: cakra-haryo-
wibowo@student.umaha.ac.id
Keywords:
Ellagic acid
Genotoxicity
Mercury
Micronucleus
Walnut

\begin{abstract}
Hydrargyrum (familiar as mercury) is a persistent transition metal element. They are known as bio-accumulative properties that are dangerous to the environment and has serious damaging effects on biota, including genetic changes or mutagenesis. Moreover, it can accumulate indirectly in the human body due to the consumption of products that have contaminated. Whereas, ellagic acid has reported as one of 13 flavonoid compounds that have potential as an antimutagen and anti-cancer in the walnuts seeds. This study was aimed to ensure the potential extent of ellagic acid extracts in walnut seeds to reducing and repairing the genotoxicity effects of mercury. Therefore, using the experimental method, this study was divided into several test treatments. Two controls treatment as a comparison of the presence of micronucleus with group tests that given a $20 \mathrm{ppm}$ mercury dosage. Then continued with the addition of walnut seed extract with various dosage $(10,15$, and $20 \mathrm{ppm})$ by oral injection continuously for two weeks as a recovery process to reducing and repairing the genotoxicity effect of mercury. The significant results showed that there are differences between pre and post-treatment. It indicated that the extract has the potential for improving and reducing the genotoxicity effect of mercury. The data were evaluated and obtained the total micronucleus from the smear of peripheral blood of mice by comparing the total micronucleus before and after giving of walnut extract.
\end{abstract}

Received: September 26th 2019

Accepted: October 31 th 2019

Published: November 14th 2019

(c) 2019 Cakra Haryo Wibowo, Essy Oktarina, Rafika Destiana Wardani, Khoirul Ngibad. Published by Institute for Research and Community Services Universitas Muhammadiyah Palangkaraya. This is an Open Access article under the CC-BY-SA License (http://creativecommons.org/licenses/by-sa/4.0/).

DOI: https:// doi.org/10.33084/ bjop.v2i2.1020.

\section{INTRODUCTION}

We had already known that mercury is one of the dangerous heavy metals appurtenant to the toxicity. The different chemical and physical properties, also the capacity as bio-accumulation and toxicity in the organism, therefore it making as a mobile element (Sizmur et al., 2018). The exposure and contamination from this heavy metal can indirectly cause serious problems. Also, it has an adverse clinical impact on biota and the environment (Bernhoft, 2012).

Primarily in nature and the aquatic environment, mercury has existed for quite a long time as mercury sulfide or the elemental mercury itself from half per million that can be found in the earth's crust (Jan et al., 2015). Thus, the effects of contamination mercury pronounced in the living organism at the level of aquatic organisms such as bivalve (Szkoda et al., 2015). These organisms (bivalve) are believed as bioaccumulation indicators and have metallothionein, which can accumulate heavy metals material in their tissues cell (Rodney et al., 2010). It sourced by the effluent which unable to concentrate both terrestrial and aquatic ecosystems, which are exposed to raised levels of environmental mercury derived from rock weathering, 
out-gassing and from the mine/smelting processes and another source (Nevado et al., 2003). Consider this heavy metal have potentially as a genotoxic material. It can change the structure genetic in the cell body of exposed, resulting in the teratogenic and carcinogenic effect chiefly in human body (Crespo-López et al., 2009).

In another case, ellagic acid is well-known as natural phenolic compounds found in fruit such as walnuts, blueberries, strawberries, raspberries, mango, longan seeds, green tea, and some vegetables (Mady \& Shaker, 2017; García-Niño \& Zazueta, 2015; Ríos et al., 2018). Plants produce it from the hydrolysis of tannins such as ellagitannin and geranin for use as protectors from microbiological infections, heavy metal poisoning, predation by insects, and pests (Aguilera-Carbo et al., 2008; Hamada et al., 2019; Yalcin et al., 2018; Shakeri et al., 2018; Ríos et al., 2018). Ellagic acid has the ability to reducing the oxidative stress in cells and has beneficial a chemopreventive substance, anti-proliferative, anti-viral, anti-bacterial and an antioxidant and had reported in recent studies (Yalcin et al., 2018; Devipriya et al., 2007). The heavy metal poisoning, especially in the cellular damage level (genetic mutation), can be detected with one of the simple parameters tests, i.e. micronucleus test. Micronucleus test can be used to determine the genotoxicity of a chemical, food, and drugs by looking at the formation of a micronucleus (small nucleus) of approximately $1 / 3-1 / 6$ of the main nucleus in cells (Bolognesi et al., 2013).

In this study, researchers wanted to extend and find out the potential of walnut seed extracts that believed contain an ellagic acid compound in repairing the genotoxicity effect of heavy metal mercury that can accumulate indirectly in the body due to consuming seafood and other contaminated foods. This study was aimed to ensure the potential extent of ellagic acid extracts in walnut seeds to reducing and repairing the genotoxicity effects of mercury. As a test animal used male albino mice by the micronucleus assay as a method of observation.

\section{MATERIALS AND METHODS}

\section{Tools and materials}

The experimental design method has been applied in this study. The all of chemical and material obtained from the laboratory at Universitas Maarif Hasyim Latif, among of May-Grünwald Giemsa staining, Wright staining, ethanol, methanol, $\mathrm{HgCl}_{2}$ reagent $\left(\mathrm{Emsure}^{\circledR}\right)$, distilled water, rotary evaporator ( $\left(\mathrm{ka}^{\circledR} \mathrm{RV} 10\right)$, hot plate with magnetic stirrer (Chimarec $\left.{ }^{\circledR}\right)$, chemical glasses (Iwaki $\left.{ }^{\circledR}\right)$, and other glass equipment.

\section{Extraction}

Approximately, $1 \mathrm{~kg}$ of peeled walnut seeds sample is dried for four days then crushed with a mortar. Further, continued maceration with $96 \%$ ethanol (Ratio $1: 1$ ) for one night to take the filtrate (repeated four repetitions). The filtrate was evaporated using rotary evaporation for several hours to obtain a pure extract from walnut seeds (Limbono, 2013).

\section{Test animal preparation}

The healthy male albino mice were obtained and acclimatized for several days before being treated. A total of 30 mice divided into five treatments, two as control groups and three as group test treatment. The control positive by giving injection intraperitoneally of cyclophosphamide $50 \mathrm{mg} / \mathrm{kg}$ BW.

\section{Exposure and recovery process}

As much as $20 \mathrm{ppm}$ of $\mathrm{HgCl}_{2}$ exposed for two weeks to mice by orally in the group treatments. Afterwards, the recovery process is done by giving various dosage of the extract $(10,15$, and $20 \mathrm{ppm})$ for two weeks.

\section{Micronucleus assay}

The micronucleus assay observed in a thousand erythrocytes cells which prepared from blood smear in 
each of the mice in the group treatment. Approximately, one drop blood spread on object-glass then fixed with methanol. Hereafter, stained with May-Grünwald, Giemsa staining, or wright staining. The observation process is using the microscope (Olympus ${ }^{\circledR}$ CX22) and Optical lab camera $\left(\right.$ OptiLab $\left.^{\circledR}\right)$ Viewer and counted with Image Raster 3 Software.

\section{Statistical analysis}

Statistical analysis was performed using the parametric method using a comparative test before and after recovery (Paired sample T-Test) in each group test. Interpretation of the results of the analysis by reading the table of significance (Sig. 2-tailed).

\section{RESULTS AND DISCUSSION}

\section{Extraction}

The extraction results of walnut seeds with the initial sample weights of approximately $1 \mathrm{~kg}$ were obtained about $23 \mathrm{~g}$ of pure extracts from walnut seeds. The extraction process was carried out after maceration four repetitions in 24 hours with $96 \%$ ethanol.

\section{Micronucleus frequency}

The control group merely used to recognize the presence of micronucleus in mice erythrocytes. The total micronucleus in the treatment group test after recovery was discovered less than the treatment group test after exposed with $\mathrm{HgCl}_{2}$. The presence of micronucleus was moderately increased in the group treatment which exposed of $\mathrm{HgCl}_{2}$ as presented in Figure 1 and Figure 2. While the total number of micronucleus frequencies after recovery and the average frequencies of micronucleus for each test group treatment are respectively presented in Table I and Table II.

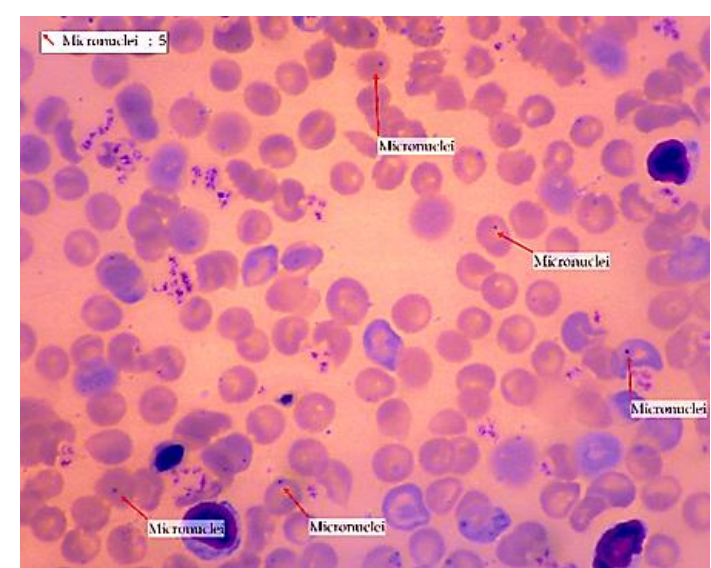

Figure 1. The presence of micronucleus in erythrocytes of mice after exposed with mercury $20 \mathrm{ppm}$

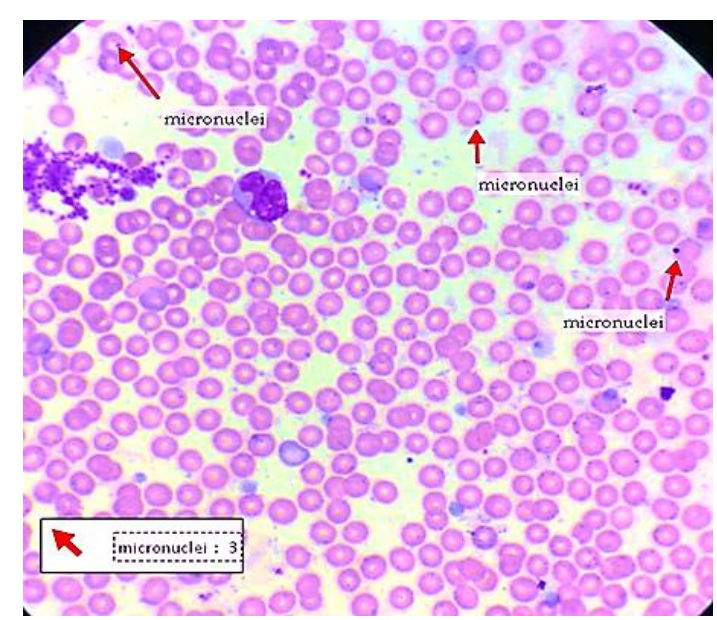

Figure 2. The presence of micronucleus in erythrocytes of mice after recovery extract E.A.

Table I. The total amount of frequencies micronucleus (positive controls)

\begin{tabular}{cccc}
\hline Slide & $\begin{array}{c}\text { The amount } \\
\text { micronucleus/1,000 cells }\end{array}$ & $\begin{array}{c}\text { Mean } \\
(\mathbf{\%})\end{array}$ & $\begin{array}{c}\text { Percentage } \\
(\mathbf{\%})\end{array}$ \\
\cline { 2 - 2 } & Control Group & & \\
\hline 1 & 13 & & \\
2 & 16 & $\mathbf{1 3 . 1}$ & $\mathbf{0 . 1 3 1}$ \\
3 & 10 & & \\
4 & 17 & & \\
5 & 13 & & \\
6 & 10 &
\end{tabular}

Table II. The total amount of frequencies micronucleus (exposed mercury)

\begin{tabular}{cccc}
\hline \multirow{2}{*}{ Slide } & \multicolumn{3}{c}{$\begin{array}{c}\text { Micronucleus after exposed mercury 20 } \\
\text { ppm (\%) }\end{array}$} \\
\cline { 2 - 4 } & A & B & C \\
\hline 1 & 19 & 18 & 12 \\
2 & 14 & 13 & 11 \\
3 & 13 & 11 & 16 \\
4 & 16 & 13 & 14 \\
5 & 13 & 14 & 10 \\
6 & 14 & 15 & 17 \\
Mean & 14.83 & 14 & 13.33 \\
\hline $\begin{array}{c}\text { Percentage } \\
(\%)\end{array}$ & 1.483 & 1.4 & 1.333 \\
\hline
\end{tabular}


Refers to Table I and Table II, we have known that micronucleus can be formed after injection orally of cyclophosphamide and $\mathrm{HgCl}_{2}$. Cyclophosphamide is widely used as an anti-tumor material, therapy cancer, and another related. However, other cases reported that this drug could have a clastogenic effect, especially on healthy cells that proliferate. Thus, causing the appearance of micronucleus in cells due to chromosomal aberrations and induces oxidative stress (Abdella, 2012). Likewise, some research in one decade summed that mercury (inorganic mercury) might lead a chromosomal genotoxicity effect through the aneugenicity and clastogenicity (Çavaş, 2008). Notwithstanding, organic mercury can generate the possibility of those effects as well. Bernhoft (2012) also reported that organic mercury has a more significant toxic effect than inorganic mercury in eliciting the toxicity.

These metals are believed to generate the possibility of genotoxic and cytotoxic more serious, which can change the composition of genetic material in the body of exposed populations. Therefore, it was occurring carcinogenic, and teratogenic effects are formed (CrespoLópez et al., 2011; Crespo-López et al., 2009). The metal mercury (especially methyl-mercury) can interact with biomolecules and can bind through hydroxyl and sulfhydryl groups (Çavuşoğlu et al., 2010). It underlies and refers to how genotoxic mechanisms occur.

Crespo-López et al. (2009) were stated that the mechanism of genotoxic of mercury through several stages. The metal mercury compound enters the cell organism through the cell membrane or even through the transport protein channels. In cells, mercury compounds will be formed as components of radical compounds and reactive oxygen species that can directly or indirectly generate the interruption of the mechanism of action of the deoxyribonucleic acid system. The components of these mercury compounds play a significant role in the organism's cell work system (whether it can be an inhibiting compound, a destructive agent or more) at the cellular level. The longer and higher the damage produced, the mercury compounds are believed to induce and increase the effects of cell damage to cause cell changes (Tchounwou et al., 2012). Even worse to increasing cancer due to the high number of ROS and free radical compounds. That believed as some cooperative compounds in bringing up the symptoms of the disease of cancer (Kumari et al., 2018).

The average of micronucleus in this research showed in the range of $14.8 \pm 2.3(\mathrm{~A}) ; 14.0 \pm 2.4(\mathrm{~B}) ; 13.3 \pm 2.8$ (C) as shown in Table II and Table IV. The data demonstrate that in the concentration of 20 ppm of exposed mercury by orally induced the presence of micronucleus in erythrocytes. It explains that genotoxic events have occurred. The presence of micronucleus can be considered as a sensitive indicator related to genotoxicity effect in the cell of the organism (da Rocha et al., 2011). Nevertheless, the range of micronucleus is depended on the dose of the agent or substance and the length of time exposure (Çavuşoğlu et al., 2010). Inversely with the results after the recovery process, the presence of micronucleus decreased significantly, as shown in Table III and Table IV. Statistical data also showed that either before and after the test treatment, there were significant differences in each test group $(\mathrm{P}<0.05)$.

Table III. The total amount of frequencies micronucleus (after recovery)

\begin{tabular}{|c|c|c|c|}
\hline \multirow[t]{2}{*}{ Slide } & \multicolumn{3}{|c|}{$\begin{array}{c}\text { Micronucleus after recovery extract of } \\
\text { walnut seeds (\%) }\end{array}$} \\
\hline & A (10 ppm) & B (15 ppm) & $\mathrm{C}(20 \mathrm{ppm})$ \\
\hline 1 & 8 & 9 & 7 \\
\hline 2 & 10 & 10 & 7 \\
\hline 3 & 7 & 8 & 8 \\
\hline 4 & 6 & 5 & 9 \\
\hline 5 & 11 & 9 & 11 \\
\hline 6 & 8 & 8 & 5 \\
\hline Mean & 8.33 & 8.16 & 7.83 \\
\hline $\begin{array}{l}\text { Percentage } \\
(\%)\end{array}$ & 0.833 & 0.816 & 0.783 \\
\hline
\end{tabular}


Table IV. The average frequencies of micronucleus (each test group treatment)

\begin{tabular}{|c|c|c|c|c|c|c|}
\hline \multirow{2}{*}{ 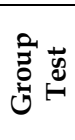 } & \multicolumn{3}{|c|}{$\begin{array}{c}\text { Exposed mercury } 20 \\
\text { ppm }\end{array}$} & \multicolumn{3}{|c|}{ After recovery extract } \\
\hline & Min & $\operatorname{Max}$ & $\begin{array}{l}\text { Average } \\
\pm \text { SD }\end{array}$ & Min & $\operatorname{Max}$ & $\begin{array}{c}\text { Average } \\
\pm S D\end{array}$ \\
\hline $\mathrm{A}$ & 13 & 19 & $14.8 \pm 2.3$ & 0 & 11 & $8.3 \pm 1.9$ \\
\hline B & 11 & 18 & $14.0 \pm 2.4$ & 5 & 10 & $8.2 \pm 1.7$ \\
\hline C & 10 & 17 & $13.3 \pm 2.8$ & 5 & 11 & $7.8 \pm 2.0$ \\
\hline
\end{tabular}

Note: Micronucleus were analyzed and counted in 1,000 cells per animal/group. The data obtained were calculated on average $\pm S D(n=$ 6/group). Statistically data: .006 (A); .003 (B); .026 (C) (Pre-post test).

\section{Chemical compounds}

The walnut seeds have various bioactive compounds. As much as nine species of compounds have been isolated. Broadly, it is derived from the secondary of metabolism walnuts, i.e. carboxylic acids, terpenes, lipids, and phenol (tannins, flavonoids, phenolic acids) (Mogana \& Wiart, 2011). A related study has been determined the pharmacology and antioxidant activities which have vast advantages for the body.

Ellagic acid has several pharmacology activities. As an anti-cancer, anti-inflammatory, anti-bacterial and fungal, anti-diabetic, hepatoprotective and scavenging the free radical (Mogana \& Wiart, 2011; Shakeri et al., 2018; Yalcin et al., 2018; García-Niño \& Zazueta, 2015). This compound is a product of hydrolysis of tannin as an ellagitannin. Structure of ellagic acid comprises four $\mathrm{OH}$ groups with a lactone ring and a dimeric derivative of benzoic acid compounds (Mady \& Shaker, 2017) as shown in Figure 3.<smiles>O=c1oc2c(O)c(O)cc3c(=O)oc4c(O)c(O)cc1c4c23</smiles>

Figure 3. Ellagic acid chemical structure

The result in this research provides a significant substantiation that mercury is one of the most agents that can adversely affect of carcinogenic effect by induced of genotoxic activities. The presence of micronucleus was a figure that there is some arrangement of chromosomal aberrations. However, the pharmacology activities of ellagic acid are far different from the mercury. Principally, ellagic acid assisted in decreasing the number of micronuclei in this research data. It shows that ellagic acid can prevent the effects of genotoxicity in the body. In general, the play role of ellagic acid is explained in Figure

4.

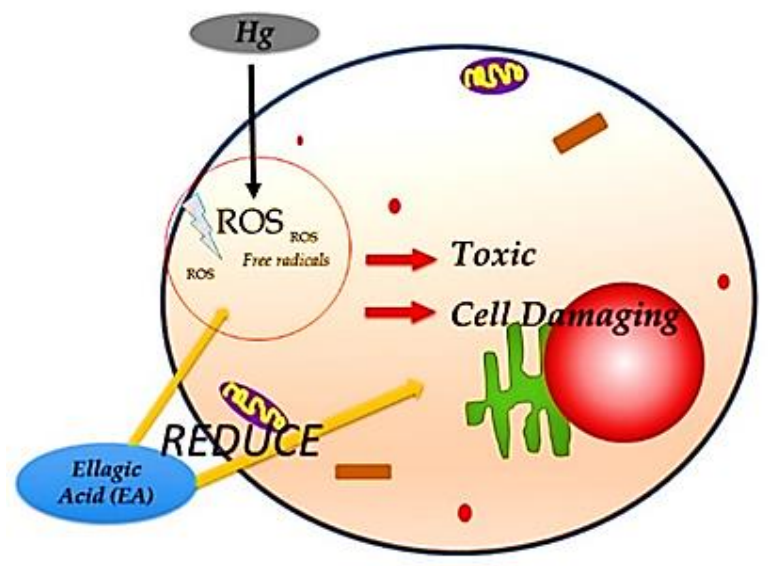

Figure 4. The schematic process between $\mathrm{Hg}$ and EA in cells

Mercury can induce the emergence of reactive oxygen species and other free radicals that are proactive to carcinogenesis by influencing changes in the genetic makeup of cells that cause genetic mutations or chromosomal aberrations. Ellagic acid can reduce the effects of free radicals by reducing damage due to $\mathrm{HgCl}_{2}$, cell oxidative stress. Ellagic acid believed to act as a chelating component to toxicity-generating compounds such as free radicals and reactive oxygen species that have unstable chemical structures. Other than that, ellagic acid can prevent changes in the structure of cell organelles (mitochondria, endoplasmic reticulum), which are specific targets of mercury toxicity (GarcíaNiño \& Zazueta, 2015).

Mercury really should be something that needs more concern. Moreover, in Indonesia - considering based on the equatorial condition besieged the sea areas and islands. It is a strategic place to utilizing the natural resources derived of most Indonesians livelihood, 
particularly in the marine field and aquatic aside from agricultural and business development. Besides, there is a possibility that people can be exposed to the effects of heavy metals, one of which is mercury through contaminated seafood. Hence from this, ellagic acid contained in walnut seeds can be an essential indicator to overcome this problem. Further research is expected to develop innovations related to the potential of compounds contained in walnut seeds.

\section{CONCLUSION}

The walnut seeds extract has potential as an antigenotoxic agent of mercury in mice erythrocytes. Also, able to reduce and repair the effects of mercury genotoxicity on mice erythrocytes. Based on this study, there is a significant difference result between before and after recovery, which is supported by a decrease in the average number of micronuclei in each test treatment.

\section{ACKNOWLEDGMENT}

This research has been a grant from the government for student program creativity in research in 2019. The author and team would like to thanks to all the assistance during the research, especially Mr Khoirul Ngibad as a lecturer that provided support and assistance, as well as Faculty of Medicine, Universitas Maarif Hasyim Latif.

\section{REFERENCES}

Abdella, E.M. 2012. Short-Term Comparative Study of the Cyclophosphamide Genotoxicity Administered Free and LiposomeEncapsulated in Mice. Iranian Journal of Cancer Prevention. 5(2):51-60.

Aguilera-Carbo, A.F., Augur, C., Prado-Barragan, L.A., Aguilar, C.N. 2008. Extraction and analysis of ellagic acid from novel complex sources. Chemical Papers. 62(4):440-444. https:/ / doi.org/10.2478/s11696-008-0042-y
Bernhoft, R.A. 2012. Mercury Toxicity and Treatment: A Review of The Literature. Journal of Environmental and Public Health. 2012:460508. https:/ /dx.doi.org/10.1155/2012/460508

Bolognesi, C., Knasmueller, S., Nersesyan, A., Thomas, P., Fenech, M. 2013. The HUMNxl scoring criteria for different cell types and nuclear anomalies in the buccal micronucleus cytome assay - an update and expanded photogallery. Mutation Research. 753(2):100-113. https://doi.org/10.1016/j.mrrev.2013.07.002

Çavuşoğlu, K., Yalçın, E., Kul, O., Yilmaz, A., Yapar, K. 2010. Detection of Genotoxicity Induced by Heavy Metal Ions and Gamma Radiation Using Micronucleus Assay in Mice: Pathological Evaluation. Sakarya University Journal of Science. 14(1):1-8.

Crespo-López, M.E., Macêdo, G.L., Arrifano, G.P., Pinheiro-Mda, C., do Nascimento, J.L., Herculano, A.M. 2011. Genotoxicity of mercury: contributing for the analysis of Amazonian populations. Environment International. $\quad 37(1): 136-141$. https://doi.org/10.1016/j.envint.2010.08.009

Crespo-López, M.E., Macêdo, G.L., Pereira, S.I., Arrifano, G.P., Picanzo-Diniz, D.L., do Nascimento, J.L., Herculano, A.M. 2009. Mercury and human genotoxicity: critical considerations and possible molecular mechanisms. Pharmacological Research. 60(4): 212-220. https://doi.org/10.1016/j.phrs.2009.02.011

Devipriya, N., Srinivasan, M., Sudheer, A.R., Menon, V.P. 2007. Effect of ellagic acid, a natural polyphenol, on alcohol-induced prooxidant and antioxidant imbalance: a drug dose dependent study. Singapore Medical Journal. 48(4):311-318.

García-Niño, W.R., Zazueta, C. 2015. Ellagic acid: Pharmacological activities and molecular mechanisms involved in liver protection. Pharmacological Research. 97:84-103. https://doi.org/10.1016/j.phrs.2015.04.008

Cavaş, T. 2008. In vivo genotoxicity of mercury chloride and lead acetate: Micronucleus test on acridine orange stained fish cells. Food and Chemical Toxicology. 46(1):352-358. https://doi.org/10.1016/j.fct.2007.08.015 
Hamada, Y., Haramiishi, R., Ojima, Y., Amakura, Y., Yoshimura, M., Sawamoto, A., Okuyama, S., Furukawa, Y., Nakajima, M. 2019. Hydrolysable tannins, gallic acid, and ellagic acid in walnut reduced 3-(4,5Dimethylthiazol-2-yl)-2,5-

Diphenyltetrazolium bromide (MTT) reduction in T-Cells cultured from the spleen of mice. PharmaNutrition. 7:100140. https://doi.org/10.1016/j.phanu.2018.100140

Jan, A.T., Azam, M., Siddiqui, K., Ali, A., Choi, I., Haq, Q.M.R. 2015. Heavy Metals and Human Health: Mechanistic Insight into Toxicity and Counter Defense System of Antioxidants. International Journal of Molecular Sciences. 16(12):29592-29630.

https:/ /dx.doi.org/10.3390/ijms161226183

Kumari, S., Badana, A.K., Mohan, G.M., Shailender, G., Malla, R. 2018. Reactive Oxygen Species: A Key Constituent in Cancer Survival. Biomarker Insights. $\quad$ 13:1177271918755391. https://doi.org/10.1177/1177271918755391

Limbono, S. 2013. Daya Antioksidan Ekstrak Etanol Biji Kenari (Canarium indicum L.) dengan Metode DPPH (1,1-Diphenyl-2picrylhydrazyl). Calyptra. 2(2):1-9.

Mady, F.M., Shaker, M.A. 2017. Enhanced anticancer activity and oral bioavailability of ellagic acid through encapsulation in biodegradable polymeric nanoparticles. International Journal of Nanomedicine. 12:7405-7417. https:/ /doi.org/10.2147/IJN.S147740

Mogana, R., Wiart, C. 2011. Canarium L.: A Phytochemical and Pharmacological Review. Journal of Pharmacy Research. 4(8):2482-2489.

Nevado, J.J.B., Bermejo, L.F.G., Martin-Doimeadios, R.C.R. 2003. Distribution of mercury in the aquatic environment at Almadén, Spain. Environmental Pollution. 122(2):261-271. https://doi.org/10.1016/S02697491(02)00290-7

Rios, J.L., Giner, R.M., Marin, M., Recio, M.C. 2018. A Pharmacological Update of Ellagic Acid. Planta Medica. 84(15):1068-1093. https:/ /doi.org/10.1055/a-0633-9492

da Rocha, C.A., da Cunha, L.A., da Silva-Pinheiro, R.H., de Oliveira-Bahia, M., Burbano, R.M. 2011. Studies of micronuclei and other nuclear abnormalities in red blood cells of Colossoma macropomum exposed to methylmercury. Genetics and Molecular Biology. 34(4):694-697. https://doi.org/10.1590/S141547572011000400024

Rodney, E., Herrera, P., Luxama, J., Boykin, M., Crawford, A., Carroll, M.A., Catapane, E.J. 2007. Bioaccumulation and Tissue Distribution of Arsenic, Cadmium, Copper and Zinc in Crassostrea virginica Grown at Two Different Depths in Jamaica Bay, New York. In Vivo. 29(1):16-27.

Shakeri, A., Zirak, M.R., Sahebkar, A. 2018. Ellagic Acid: A Logical Lead for Drug Development?. Current Pharmaceutical Design. 24(2):106-122. https://doi.org/10.2174/13816128236661711 15094557

Sizmur, T., O’Driscoll, N., Cai, Y. 2018. JES Special issue in Mercury Biogeochemistry and Fate. Journal of Environmental Sciences. 68:1-4. https://doi.org/10.1016/j.jes.2018.05.020

Szkoda, J., Durkalec, M., Nawrocka, A., Michalski, M. 2015. Mercury concentration in bivalve molluscs. Bulletin of the Veterinary Institute in Pulawy. 59(3):357-360. https://doi.org/10.1515/bvip-2015-0053

Tchounwou, P.B., Yedjou, C.G., Patlolla, A.K., Sutton, D.J. 2012. Heavy Metals Toxicity and the Environment. EXS. 101:133-164. https:/ /dx.doi.org/10.1007/978-3-7643-83404_6

Yalcin, G., Demirbag, C., Bahsi, I., Ozgul, L., BilgicAlkaya, D., Onurlu, H.I., Ayaz-Seyhan, S. 2018. Determination of Ellagic Acid in the Wastes of Walnut, Chestnut, and Pomegranate Grown in Turkey. In Jayaprakasha, G.K., Patil, B.S., Gattuso, G. (Eds.), Advances in Plant Phenolics: From Chemistry to Human Health (81-103). Washington, DC: ACS Publications. https://doi.org/10.1021/bk-2018-1286.ch005 